\title{
Measuring seagrass photosynthesis: methods and applications
}

\author{
João Silva ${ }^{1, *}$, Yoni Sharon ${ }^{2,3}$, Rui Santos ${ }^{1}$, Sven Beer ${ }^{3}$ \\ ${ }^{1}$ Marine Plant Ecology Research Group, Center of Marine Sciences (CCMar), Universidade do Algarve, \\ Campus de Gambelas, 8005-139 Faro, Portugal \\ ${ }^{2}$ The Interuniversity Institute for Marine Sciences, POB 469, Eilat 88103, Israel \\ ${ }^{3}$ Department of Plant Sciences, Tel Aviv University, Tel Aviv 69978, Israel
}

\begin{abstract}
This review originates from a keynote lecture given at the recent 8th Group for Aquatic Productivity (GAP) workshop held in Eilat, Israel. Here we examine the most important methodologies for photosynthetic measurements in seagrasses and evaluate their applications, advantages and disadvantages, and also point out the most relevant results. The most commonly used methodologies are based on oxygen $\left(\mathrm{O}_{2}\right)$ evolution and chlorophyll fluorescence measurements. $\mathrm{O}_{2}$-based methodologies allowed for the first approaches to evaluate seagrass productivity, whereas chlorophyll a fluorescence has more recently become the choice method for in situ experiments, particularly in evaluating photosynthetic responses to light and assessing stress responses. New methodologies have also emerged, such as $\mathrm{O}_{2}$ optodes, underwater $\mathrm{CO}_{2}$ flux measurements, geo-acoustic inversion and the eddy correlation technique. However, these new methods still need calibration and validation. Our analysis of the literature also reveals several significant gaps in relevant topics concerning seagrass photosynthesis, namely the complete absence of studies on deep-growing populations that photosynthesise under extreme low light conditions and the uncertainties about the true degree of seagrass carbon limitation, which limits our ability to predict responses to global changes.
\end{abstract}

KEY WORDS: Seagrass photosynthesis $\cdot \mathrm{O}_{2}$ evolution $\cdot$ Chlorophyll a fluorescence $\cdot$ Carbon uptake . $\mathrm{CO}_{2}$ flux

\section{INTRODUCTION}

Early studies on seagrass photosynthesis (e.g. Drew 1978) usually began by explaining that seagrasses are relatively primitive monocotyledons, closely related to freshwater plants but able to live in the marine environment. Presently, many introductions start by highlighting the importance of seagrasses in overall marine productivity and their subsequent economical importance (e.g. Duarte \& Cebrián 1996, Costanza et al. 1997, Duarte \& Chiscano 1999). This shift of emphasis indicates the evolution of seagrass perception in global biological science and reflects the contribution of the increasing number of physiological and ecophysiological studies dealing with this plant group.
Seagrass photosynthesis was, until recently, most commonly measured in laboratory experiments, usually by incubating leaf segments in closed chambers and determining initial and end $\mathrm{O}_{2}$ values, or by following continuous $\mathrm{O}_{2}$ evolution in the chambers with Clark-type electrodes. These methods have provided most of the fundamental information on seagrass responses to factors such as light, temperature and nutrients (comprehensively reviewed by Lee et al. 2007) and on the mechanisms of carbon uptake and fixation by these plants (Beer et al. 2002). However, they are extremely intrusive, as they involve plant removal from the natural environment and a high degree of manipulation (Beer et al. 2001).

In situ measurements of photosynthetic activity in seagrasses were made possible after the development 
of a submersible pulse-amplitude modulated (PAM) fluorometer (applied initially by e.g. Beer et al. 1998, Ralph et al. 1998, Björk et al. 1999, Beer \& Björk 2000). Recently, an infrared gas analysis (IRGA) technique has been adapted for in situ continuous dissolved $\mathrm{CO}_{2}$ flux measurements using incubation chambers connected to the analyser at the surface (Silva et al. 2008). While PAM fluorometry determines photosynthetic traits of individual plants, the IRGA method measures the rates of gas exchange at the community level. A combination of both methods may give real-time information on both the photosynthetic characteristics of seagrass plants and the community $\mathrm{CO}_{2}$ exchange of undisturbed seagrass meadows.

In situ experiments are less intrusive and deal with the plants in their natural habitat, hence the photosynthetic measures incorporate the influences of all ambient parameters. However, the control of experimental conditions is limited, and insights on specific processes are difficult to obtain. On the other hand, laboratory experiments allow for the control and manipulation of most external parameters and are most suited to obtain very specific information, e.g. data on biochemical processes related to photosynthesis. The general downside of laboratory experiments is the difficulty in extrapolating results to the natural environment, e.g. time-related patterns of photosynthetic activity.

We review the fundamental aspects of the most important methodologies used for photosynthetic measurements in seagrasses, detailing their field of application and highlighting the most relevant results achieved. Some new and promising techniques are presented and a critical analysis of the major advantages and disadvantages of each method is given. Significant gaps in this area of research are discussed and presented as potential pathways for future work.

\section{MEASURING SEAGRASS PHOTOSYNTHESIS}

\section{$\mathrm{O}_{2}$ measurements}

Measuring the $\mathrm{O}_{2}$ evolved during photosynthesis is one of the oldest and simplest ways of quantifying the photosynthetic activity of plants. In the aquatic environment, $\mathrm{O}_{2}$ concentration can be determined: (1) chemically by Winkler titration, (2) polarographically using $\mathrm{O}_{2}$ electrodes, or (3) optically using $\mathrm{O}_{2}$ optodes.

\section{The Winkler method}

When applied to seagrasses, the Winkler method (see Strickland \& Parsons 1972, adapted to field use by Drew
\& Robertson 1974, Grasshoff et al. 1983) usually involves enclosing the plants in sealed containers (or 'bottles') and leaving them to incubate for a period of time. The increase or decrease of the $\mathrm{O}_{2}$ concentration during the incubation period provides a measure of either net photosynthesis (in the illuminated transparent bottles) or respiration (in darkened bottles), respectively. Gross photosynthesis can be calculated by correcting the net photosynthetic rates obtained with the rate of dark (mitochondrial) respiration. The Winkler method remains one of the most accurate ways of measuring dissolved $\mathrm{O}_{2}$ concentrations, arguably better than most commercial field-going $\mathrm{O}_{2}$ probes. Nevertheless, there are a number of downsides to this methodology, namely: (1) the need to detach and cut down plant samples (since whole plants usually do not fit into the bottles), compromising integrity and inducing stress (except when this method is used to measure $\mathrm{O}_{2}$ before and after whole-community incubations); (2) the difficulty in maintaining adequate homogenization of the medium during incubations, leading to increased boundary layers and resulting in underestimations of photosynthetic rates (Koch 1994); (3) the likelihood of $\mathrm{O}_{2}$ saturation and/or inorganic carbon depletion during the incubation period, both resulting in photosynthetic inhibition due to, for example, photorespiration (Beer 1989) and carbon limitation, respectively (neither verifiable in real-time as only initial and final $\mathrm{O}_{2}$ concentrations are determined); and (4) the difficulty in ensuring a proper homogeneous or in situ-like illumination of the plant sample. This method thus allowed for the very first approaches to in situ and laboratory experiments of seagrass productivity: Drew $(1978,1979)$ investigated the seasonal variation in the photosynthetic activity of Cymodocea nodosa and Posidonia oceanica, generated photosynthesis-irradiance $(P-E)$ curves and measured dark respiration in C. nodosa, Halophila stipulacea, Phyllospadix torreyi, Posidonia oceanica, Zostera angustifolia and Z. marina, determining the effects of temperature on photosynthesis and calculating compensation and saturation irradiances for those species. Over the years, the effects of light, temperature, salinity and pressure on seagrass photosynthesis were further investigated using this technique in Halodule uninervis, Halophila stipulacea and Halophila ovalis (Beer \& Waisel 1982, Wahbeh 1983), Z. muelleri (Kerr \& Strother 1985), C. nodosa (Pérez \& Romero 1992, Zavodnik et al. 1998, Olesen et al. 2002) and Posidonia oceanica (Olesen et al. 2002). Recently, a few studies focusing on whole-community metabolism also used Winkler titrations to determine $\mathrm{O}_{2}$ concentrations before and after incubations in benthic chambers (Barrón et al. 2004, Gazeau et al. 2005a,b). Nevertheless, the long incubation times used in these studies raise the concern that photosynthesis may be underestimated due to the decreased carboxylase activity of Rubisco in response to 
the increase in $\mathrm{O}_{2}$ and decrease in $\mathrm{CO}_{2}$ concentrations within the incubation chambers.

\section{$\mathrm{O}_{2}$ electrodes}

Electrochemical sensors for $\mathrm{O}_{2}$ measurements are commonly known as Clark-type $\mathrm{O}_{2}$ electrodes (after their inventor, Leyland C. Clark). These electrodes are composed of a platinum cathode and a silver anode separated by a salt bridge. An electron flow is set in motion when a control unit applies a small electric potential to the system. The current flow is proportional to the $\mathrm{O}_{2}$ consumed at the cathode and can be either analogically plotted or converted into a digital signal to be recorded by a control unit (Walker 1987).

Clark-type electrodes are available in a number of options such as handheld units, bench oxymeters or incorporated in complete commercially available setups. Whereas handheld units, with low accuracy, are mainly useful for indicative measurements of dissolved $\mathrm{O}_{2}$ (DO) concentrations, bench-top oxymeters, with better performance, have been used in conjunction with customized incubation chambers, allowing for versatile and tailor-made apparatuses (Smith et al. 1984, Fourqurean \& Zieman 1991, Koch 1994, Masini et al. 1995, Masini \& Manning 1997). Complete systems comprised of Clark-type electrodes attached to water-jacketed incubation chambers are also available on the market, namely those by Hansatech Instruments and Rank Brothers. These laboratory systems provide the highest available resolution and accuracy and have become standard in photosynthetic research. $\mathrm{O}_{2}$ electrodes such as these are probably among the best tools to investigate photosynthetic mechanisms and determine the photosynthetic capacities of seagrasses. Photosynthetic capacity refers strictly to the photosynthetic rate obtained under ideal conditions, i.e. with non-limiting dissolved inorganic carbon (DIC) supplies, nutrients and light and at optimum temperature (Jones 1994). Such demanding conditions are relatively easy to reproduce and maintain in a small, highly controlled environment such as an $\mathrm{O}_{2}$ electrode-coupled reaction vessel, but almost impossible to achieve in any other environment.

$\mathrm{O}_{2}$ electrodes are mostly used in 2 general types of experimental setups: (1) those in which whole plants or plant sections are incubated for a selected period of time in a sealed container and $\mathrm{O}_{2}$ concentrations are determined at the beginning and at the end of the incubations (endpoint incubations), and (2) those in which an $\mathrm{O}_{2}$ electrode is coupled to the incubation chamber and $\mathrm{O}_{2}$ evolution is continuously monitored.

Using endpoint incubations, Evans et al. (1986) evaluated temperature acclimation effects on the photo- synthetic rates of Zostera marina and Ruppia maritima leaf tips (from Chesapeake Bay) while Terrados \& Ros (1995) investigated the seasonal variation of temperature effects on the photosynthesis and respiration of shallow Mediterranean Cymodocea nodosa. Koch \& Dawes (1991) searched for differences in $P$-E curves between 2 ecotypes of $R$. maritima from Florida and North Carolina and Enríquez et al. (1995) determined a series of $P-E$ relationships in plant sections in an attempt to identify a relationship between the photosynthetic activity of several Mediterranean macrophytes and their morphological characteristics. Invers et al. (1997) investigated the effects of $\mathrm{pH}$ on photosynthetic rates of Zostera noltii, C. nodosa and Posidonia oceanica; Ramírez-García et al. (1998) incubated pre-desiccated leaves of Phyllospadix scouleri and Phyllospadix torreyi in glass bottles to assess the effects of different previous air-exposure periods on the photosynthetic activity; and Ruiz \& Romero (2001) compared light response curves among Posidonia oceanica samples harvested from an in situ multilevel shading experiment. Finally, Alcoverro et al. (1998, 2001) examined the seasonal and age-dependence of Posidonia oceanica photosynthetic parameters and its annual carbon balance; Invers et al. $(1999,2001)$ evaluated the role of carbonic anhydrase in the inorganic carbon supply to Posidonia oceanica and C. nodosa; and Bintz \& Nixon (2001) measured respiration and photosynthetic rates of whole-plant $Z$. marina seedlings at 3 different light levels. Hence this type of setup has been used to determine photosynthetic light response curves and to evaluate the effects of seasonality, morphological characteristics, leaf age dependence, shading, temperature, desiccation and $\mathrm{pH}$ on seagrass photosynthesis.

Systems based on continuous $\mathrm{O}_{2}$ measurement have been used both in laboratory and field experiments. Most laboratory work has been done using the commercially available integrated systems. Dennison \& Alberte (1982) investigated the effects of light availability on Zostera marina photosynthesis and growth; seasonal variations in photosynthetic light responses were evaluated in $Z$. noltii from the Netherlands (Vermaat \& Verhagen 1996), in Z. marina and Phyllospadix scouleri from California (Cabello-Pasini \& Alberte 1997) and in 2 Texan Thalassia testudinum populations (Herzka \& Dunton 1997); Kaldy \& Dunton (1999) determined $P$-E relationships in T. testudinum laboratorygrown seedlings; Cabello-Pasini et al. (2002) compared the maximum photosynthetic rates of an open-ocean $Z$. marina population with that from a coastal lagoon; Invers et al. (2001) measured continuous $\mathrm{O}_{2}$ evolution in Z. marina and P. torreyi from the eastern Pacific; Peralta et al. $(2000,2005)$ compared photosynthetic light response curves between $2 Z$. noltii morphotypes; 
Silva \& Santos (2004) correlated photosynthetic $\mathrm{O}_{2}$ release with electron transport rates in the same species; and Cayabyab \& Enríquez (2007) determined the photosynthetic light responses of $T$. testudinum plants submitted to 3 distinct light treatments. These integrated $\mathrm{O}_{2}$ measuring systems have the advantage of measuring net gas exchange, which may be correlative to growth, but their often small size and the fact that the plants (or usually only leaves) must be enclosed, limits the reliability of the results for extrapolation to true, unobstructed, in situ conditions.

The above-mentioned systems have also been widely used in experiments addressing the mechanisms of carbon uptake, particularly those concerning the use of $\mathrm{HCO}_{3}{ }^{-}$by seagrasses. Using Clark-type $\mathrm{O}_{2}$ electrode-based experimental setups, the use of $\mathrm{HCO}_{3}{ }^{-}$ as a DIC source was demonstrated for Zostera muelleri from Australia (Millhouse \& Strother 1986), Thalassia testudinum from Florida (Durako 1993), Posidonia australis from Australia (James \& Larkum 1996) and $Z$. marina (Beer \& Rehnberg 1997). Beer \& Koch (1996) used this kind of system to simulate primitive inorganic carbon conditions in the Cretaceous and compare the photosynthetic performance of $Z$. marina and $T$. testudinum under those conditions with that under present day ocean conditions. Zimmerman et al. (1997) evaluated the effects of $\mathrm{CO}_{2}$ enrichment on $Z$. marina productivity and light requirements with a similar apparatus. Björk et al. (1997) investigated inorganic carbon use in 8 seagrass species from the Eastern African coast, by measuring the response of photosynthesis to increased inorganic carbon levels. In the same study, Halophila ovalis, Cymodocea rotundata and Syringodium isoetifolium also revealed their ability to use $\mathrm{HCO}_{3}{ }^{-}$as an inorganic carbon source. Hellblom et al. (2001) assessed the effects of commonly used buffers on the photosynthetic rates of $Z$. marina and were able to identify 2 mechanisms of $\mathrm{HCO}_{3}{ }^{-}$utilization, one of them firstly reported for seagrasses based on extruded protons-mediation of $\mathrm{HCO}_{3}^{-}$uptake. Mercado et al. (2003) investigated the affinity for DIC and the presence of different mechanisms of $\mathrm{HCO}_{3}^{-}$ use in 2 morphotypes of intertidal $Z$. noltii from southern Portugal. They found that this species had a low affinity for $\mathrm{HCO}_{3}{ }^{-}$, particularly the lower intertidal morphotype. Further, photosynthetic pathways, mechanisms of inorganic carbon acquisition, effects of carbon enrichment and buffer additions and the molar relationships between $\mathrm{O}_{2}$ release and electron transport have been elucidated using such $\mathrm{O}_{2}$ electrode systems. On the other hand, extrapolation of the results obtained in these small-volume, laboratory-bound systems to in situ conditions may be rather incorrect.

A few authors have built custom chambers with coupled electrodes for specific experiments. Smith et al.
(1984) used a custom-made 2-chambered apparatus connected to a Clark-type $\mathrm{O}_{2}$ electrode to demonstrate and quantify the transport of $\mathrm{O}_{2}$ from the shoots to the root-rhizome system of Zostera marina. In a very elegant experimental design, the authors incubated intact shoots, separating the leaves from the root-rhizome system in 2 adjacent compartments with separate media and illumination. By quantifying the $\mathrm{O}_{2}$ taken up or released by the root-rhizome system in the absence or presence of shoot illumination, it was possible to elucidate the role of the light environment in the maintenance of root aerobiosis. This line of research was further pursued by Greve et al. (2003) and Binzer et al. (2005), using microelectrodes inserted directly into seagrass rhizomes. These studies significantly advanced our understanding of metabolic integration in seagrasses. They provided the first in situ measurements of the fraction of photosynthetically evolved $\mathrm{O}_{2}$ that is channelled down internally to below-ground tissues and eventually leaked to ensure aerobiosis in the rhizosphere. Fourqurean \& Zieman (1991) used a custom-made transparent acrylic chamber with a coupled Clark-type polarographic $\mathrm{O}_{2}$ probe to determine the light-response curves of whole Thalassia testudinum leaves from south Florida. Koch (1994) examined the effects of hydrodynamics and boundary layer thickness on the photosynthetic rates of $T$. testudinum and Cymodocea nodosa. In that study, plant samples were incubated in a temperature-controlled microcosm with an externally recirculated incubation medium. $\mathrm{O}_{2}$ evolution was continuously monitored by a Clark-type $\mathrm{O}_{2}$ electrode installed at an intermediate point of the system. Masini et al. (1995) and Masini \& Manning (1997) determined photosynthetic light responses in Posidonia sinuosa, P. australis, Amphibolis griffithii and A. antarctica in a custom-built tubular incubation chamber with an external water recirculation circuit. Water flowing in the circuit was passed through a highresolution $\mathrm{O}_{2}$ sensor, recording $\mathrm{O}_{2}$ values every $15 \mathrm{~s}$.

Some researchers brought high precision $\mathrm{O}_{2}$ electrodes to the field, connecting them to benthic incubation chambers to monitor the whole-community $\mathrm{O}_{2}$ release and/or consumption. Dunton \& Tomasko (1994) and Major \& Dunton (2000) incubated, respectively, whole Halodule wrightii and Syringodium filiforme plants from south Texas, in situ, using transparent acrylic chambers placed on the seabed. Continuous $\mathrm{O}_{2}$ evolution within the chambers was followed using a high-resolution dissolved $\mathrm{O}_{2}$ probe installed on a boat at the surface. In both studies, the authors also conducted laboratory measurements of $P$-E curves in leaf segments using water-jacketed incubation chambers with coupled $\mathrm{O}_{2}$ electrodes. Field and laboratory measurements were compared, and in both studies the photosynthetic efficiency $(\alpha)$, expressed as the initial 
slope of $P$-E curves, was shown to be highly overestimated in laboratory measurements. Other significant differences, observed in the compensation intensity $\left(I_{\mathrm{C}}\right)$ and in respiration, highlighted the advantages of in situ measurements. Benthic chambers with continuous $\mathrm{O}_{2}$ monitoring were also used by Plus et al. (2001) to determine primary production and respiration of Zostera noltii beds in the Thau lagoon in South France.

\section{$\mathrm{O}_{2}$ optodes}

Optodes are sensors for optical detection of chemical species. The common measuring principle is the use of an indicator dye (immobilized on the tip of an optic fibre or on a planar surface), the colour of which changes as a function of variations in the concentration of the analyte. Optodes can be used to quantify a number of analytes, e.g. $\mathrm{O}_{2}$ and $\mathrm{CO}_{2}$. Several indicator dyes can be used to build $\mathrm{O}_{2}$ optodes, providing that their luminescence intensity and lifetime are affected by $\mathrm{O}_{2}$ concentration. A measurement is obtained when an excitation light is supplied via the fibre and the luminescence quenching of the dye is guided in the opposite direction and digitally imaged (Glud 2008). The quenching magnitude is then directly proportional to the $\mathrm{O}_{2}$ concentration (Kühl \& Polerecky 2008). Optodes, mostly in their planar configuration, were developed as a tool for 2-dimensional measurements of $\mathrm{O}_{2}$ profiles in benthic communities. The 2-dimensional $\mathrm{O}_{2}$ imaging allows a higher degree of spatial integration than single-point microsensor measurements, and thus planar $\mathrm{O}_{2}$ optodes are seen as a powerful tool to describe spatial and temporal benthic $\mathrm{O}_{2}$ distribution patterns and their dynamics (Glud et al. 2001, Glud 2008).

In recent studies (Jensen et al. 2005, Frederiksen \& Glud 2006), planar optodes were used for the first time to investigate $\mathrm{O}_{2}$ leakage in the rhizosphere of the seagrass Zostera marina. In both cases, $\mathrm{O}_{2}$ imaging revealed high spatial and temporal dynamics of the $\mathrm{O}_{2}$ distribution in the rhizosphere and identified root tips as the zone where the oxic areas were more significant, and thus where most leakage occurred. One apparent drawback of planar optodes is that the measurements are conducted along an artificial wall, which represents a significant alteration of the natural sediment structure, with possible effects on $\mathrm{O}_{2}$ spatial dynamics. Tapered $\mathrm{O}_{2}$ micro-optodes provide 1dimensional measurements and are seen as a possible alternative to micro-electrodes, with the advantage of not consuming $\mathrm{O}_{2}$. Miller \& Dunton (2007) essayed the use of micro-optodes to measure photosynthetic rates in incubated Laminaria hyperboria discs, and their results agreed with published ones obtained by established methods.
Both planar and tapered $\mathrm{O}_{2}$ optodes appear as promising techniques for use in seagrass photosynthetic research. Their full potential is yet to be explored, and further studies are necessary, particularly to compare and validate $\mathrm{O}_{2}$ optodes against other established methods.

\section{Chlorophyll fluorescence}

When photons within the photosynthetically active radiation $(\mathrm{PAR})$ region strike the photosynthetic pigment molecules, these become excited. Their excitation energy is, during the following de-excitation, transferred towards the reaction centre's special chlorophyll a molecules, whose electrons also become excited and are channelled to an electron acceptor molecule (Quinone $A, Q_{A}$ ). However, a significant portion of the energy released by de-excitation (or decay) back to ground-level does not enter the photochemical process and is, instead, released (or dissipated) as heat or fluorescence, i.e. the emission of photons of longer wavelength than the ones absorbed (Schreiber et al. 1998). It is the nature of an inverse relationship between chlorophyll a fluorescence and photochemistry that enables the use of the former to be used in the investigation of many aspects of the photosynthetic process.

Conventional fluorometers emit identical actinic (or photosynthesis-causing) and excitation lights. The high-wavelength fluorescent light is separated from the actinic light by filters before reaching the instrument's detector. This allows for a strong fluorescence signal, but makes quenching analysis and quantum yield measurements difficult. In modulated fluorometers, light is emitted in a succession of alternate light-dark periods, which enables a more clear separation of the fluorescence signal from ambient light. PAM fluorometers, the more recent type, emit continuous short measuring-light pulses of red or blue light. As the fluorescence signal caused by this measuring light is captured during the very short pulse periods, external disturbances, background signals and transient artefacts are eliminated and do not mask the fluorescence signal (Schreiber et al. 1998).

In PAM fluorometers, the short pulses of measuring light induce the emission of a fluorescence signal termed $F_{\mathrm{o}}$ or $F_{\mathrm{s}}$ (depending on whether the plant was dark-adapted or not, respectively). When a saturating light pulse of some $0.8 \mathrm{~s}$ duration is applied to the plant sample, all reaction centres become reduced (or 'closed') and the fluorescence emission is maximal $\left(F_{\mathrm{m}}\right.$ or $F_{\mathrm{m}}$ ', again dependent on the previous dark-adaptation or not, respectively; complete notation of fluorescence terms can be found in van Kooten \& Snel 1990). In the case of dark-adapted plants, the maximum pho- 
tochemical efficiency of PSII is then given by $\Phi_{\mathrm{PSII}}=$ $F_{\mathrm{m}}-F_{\mathrm{o}} / F_{\mathrm{m}}$ or simply $F_{\mathrm{v}} / F_{\mathrm{m}}$. This parameter, besides expressing the potential for PSII photochemistry, is commonly used to investigate the onset and recovery of stress situations due to its sensitivity to plant stress (Beer et al. 2001). In illuminated samples, the same measurement provides the effective quantum yield $(Y)$ which is given by $Y=F_{\mathrm{m}}{ }^{\prime}-F_{\mathrm{s}} / F_{\mathrm{m}}{ }^{\prime}=\Delta F / F_{\mathrm{m}}{ }^{\prime}$ (Genty et al. 1989). When $Y$ is measured at steady-state at a known irradiance $(I)$, the rate at which electrons are carried through the transport chain past Photosystem II (PSII) (electron transport rate, ETR) can be estimated, ETR = $Y \times I \times \mathrm{AF} \times 0.5$, where AF is the absorption factor (Beer et al. 2001) and 0.5 expresses an equal distribution of the absorbed photons between PSII and PSI (Schreiber et al. 1995, see however Grzymski et al. 1997 for alternative distribution values in some forms of macroalgae). Depending on the research-specific goals, or if AF cannot be obtained, it may not always be necessary or relevant to use absolute values of ETR. In such cases, relative ETRs (rETR), expressed as the product of the effective quantum yield by irradiance, can also be used (for a full review of the optical properties and absorptances of seagrass leaves see Durako 2007). Absolute ETRs are mandatory, for instance, when comparisons of ETR and gross photosynthetic $\mathrm{O}_{2}$ evolution are made (Beer et al. 2001). Unlike terrestrial plants, where an AF value of 0.84 is often accepted as a valid value, seagrass leaves present high variability in this parameter (Durako 2007).

Chlorophyll fluorescence measurements have been applied to seagrass research from the mid-1990s. Two main types of fluorometers have been used to investigate a wide array of questions. A non-modulated or continuous excitation fluorometer (PEA, Hansatech Instruments) was used in laboratory experiments by Dawson \& Dennison (1996) to assess the effects of increased ultraviolet radiation and elevated PAR on various morphological and physiological parameters of 5 Australian seagrass species. The same type of instrument was also used by Enríquez et al. (2002) to examine variations in photosynthetic activity along the leaves of Thalassia testudinum in the Caribbean Sea. Continuous excitation fluorometers allow for high temporal resolution measurements, an essential condition to investigate the kinetics of the Kautsky induction curve (Buschmann \& Lichtenthaler 1988, Enríquez et al. 2002). Given that this kind of fluorometry does not allow the separation of fluorescence emission from ambient light, measurements can only be performed in dark-adapted samples, which restricts their usefulness to high quality $F_{\mathrm{v}} / F_{\mathrm{m}}$ determinations and the abovementioned induction kinetics analysis.

Most research involving fluorescence determination of seagrasses has been conducted using PAM fluoro- meters, mainly those produced by Walz. This instrument allows measurements to be conducted in full sunlight, thanks to a special emitter-detector unit that separates the fluorescence signal from ambient light (Schreiber et al. 1988). Most PAM fluorometers are portable and one model, the Diving-PAM, is adapted for underwater operation. The coupling of these characteristics opened the way for autonomous in situ measurements of effective quantum yields on plants exposed to natural conditions. Novel, automated, multichannel chlorophyll fluorometers, first described by Runcie \& Riddle (2004) and able to withstand prolonged deployments, were used to investigate light acclimation processes of Halophila stipulacea (Runcie et al. 2009, this Theme Section) during the recent 8th Group for Aquatic Productivity (GAP) workshop. Those instruments allow autonomous measurements to be conducted for longer periods ( $>24 \mathrm{~h}$ ), opening new and exciting possibilities in seagrass photosynthetic research. Whether in the field or in laboratory experiments, PAM fluorescence has been used in the evaluation of time- or space-related variations in photosynthesis, with insights on the dynamic behaviour of the photosynthetic apparatus of several seagrass species (Silva \& Santos 2003). $P$ - $E$ curves can be obtained by PAM fluorescence when $Y$ is determined along an irradiance gradient. If this gradient is imposed by the fluorometer's own actinic light source, usually only short (up to minutes) light steps are allowed, due to instrument limitations. The resulting curves are named rapid light curves (RLCs) due to this feature, and must be interpreted differently from conventional light response curves, although they are graphically similar. The critical difference between RLCs and conventional $P$ - $E$ curves is that the ETRs used to draw the curves are not measured at steady-state conditions, given the short exposure at each light step (Ralph \& Gademann 2005 and references therein). Still, RLCs provide important ecophysiological information, namely through the interpretation of curve defining parameters, similar to those of conventional light response curves (Beer et al. 1998, Ralph \& Gademann 2005, Saroussi \& Beer 2007).

Conventional light response curves can be determined in nature using chlorophyll fluorescence, as long as an external light source supplies more extended periods of illumination at each light step. This type of curve has been obtained mainly with the goal of comparing ETRs with gross $\mathrm{O}_{2}$ production in the search for an expedient and field-going methodology to estimate photosynthetic rates. In these experiments, $\mathrm{O}_{2}$ production and ETRs are simultaneously measured at several irradiances, always at steady state. Considering that $4 \mathrm{~mol}$ of electrons are carried through the transport chain for each mol of $\mathrm{O}_{2}$ produced, there is a theoretical molar ratio of 0.25 
between $\mathrm{O}_{2}$ production and ETR (Walker 1987). In order for ETR measurements to be used as proxies for estimations of actual photosynthetic production, 2 basic conditions must be met: both a linear relationship between $\mathrm{O}_{2}$ production and ETR, and a $0.25 \mathrm{O}_{2} /$ ETR molar ratio must be observed, preferably along a comprehensive range of light levels (Silva \& Santos 2004).

Beer et al. (1998) published the first comparison between photosynthetic $\mathrm{O}_{2}$ evolution and ETRs in seagrasses. The authors examined the $\mathrm{O}_{2}$ /ETR relationship in Cymodocea nodosa, Halophila stipulacea and Zostera marina and found molar values of 0.3, 0.12 and 0.5 , respectively, although only $C$. nodosa presented a clearly linear relationship between the evolved $\mathrm{O}_{2}$ and the transported electrons. Beer \& Björk (2000) observed a linear relationship and a ratio of 0.28 in Halophila ovalis, and a contrasting curvilinear relationship and a ratio of 0.57 in Halodule wrightii. Silva \& Santos (2004) obtained a linear relationship and a ratio of 0.15 in Zostera noltii. Enríquez \& Rodríguez-Román (2006) verified a linear relationship and a ratio of 0.25 for Thalassia testudinum, but only for irradiances $<170 \mu \mathrm{mol}$ $\mathrm{m}^{-2} \mathrm{~s}^{-1}$. Common to all these studies are: (1) the observation of quite disparate molar ratios, many of them far from the theoretical stoichiometry and ranging from 0.12 to $0.57,(2)$ the recording of different initial slopes of ETR and $\mathrm{O}_{2}$ response curves, and (3) the fact that ETR tends to saturate at higher irradiances than $\mathrm{O}_{2}$ evolution. Putative explanations for problems concerning ETR calculations are electron-cycling around PSI and non-photochemical quenching in PSII reaction centres at saturating light levels (Franklin \& Badger 2001). Uncertainties in $\mathrm{O}_{2}$ evolution may be related to photorespiration, which can be an important $\mathrm{O}_{2}$ sink (e.g. Flexas \& Medrano 2002 and references therein), or the Mehler reaction, in which $\mathrm{O}_{2}$ is photoreduced at PSI with the production of superoxide radicals (Asada 1999). The Mehler reaction alone can represent up to $10 \%$ of the ETR (Makino et al. 2002), corresponding to a similar deviation in the theoretical stoichiometry of the photosynthetic process. The conversion of net to gross photosynthesis is also likely to introduce additional errors (discussed in Silva \& Santos 2004), depending on how dark respiration is estimated.

One of the most common applications of PAM fluorescence in seagrass research has been the study of temporal and spatial variation in photosynthesis patterns. In a set of laboratory experiments, Ralph (1996) examined the effects of daily irradiance patterns in the photosynthetic activity of Halophila ovalis, comparing laboratory-grown plants with wild ones, and observed very different patterns among the 2 groups in response to different light regimes. Since these experiments, and taking advantage of the portability and water resistance of the new Diving-PAM, most of the studies ad- dressing similar questions have been conducted in situ, either in the intertidal area or underwater, using SCUBA. Daily variation in seagrass photosynthesis, as influenced by ambient irradiance, has been investigated in situ for Zostera noltii and Cymodocea nodosa in southern Europe (Silva \& Santos 2003), Posidonia australis in Australia (Runcie \& Durako 2004), Halophila stipulacea in the Red Sea (Sharon \& Beer 2008) and Thalassia testudinum in Florida (Belshe et al. 2008). Spatial variation in photosynthetic activity has also been investigated, at scales ranging from within- to among-shoot variability up to landscape-level patterns. Ralph \& Gademann (1999) measured $F_{\mathrm{v}} / F_{\mathrm{m}}$ ratios along the leaves of Posidonia australis while assessing the effect of epiphytes on the plants' photosynthesis. Durako \& Kunzelman (2002) evaluated the variability of photosynthesis within the shoots of $T$. testudinum in Florida, and went further, examining differences between shoots from healthy and die-off patches and looking at temporal variation among ca. 300 sampling stations distributed among several basins. Turner \& Schwarz (2006) conducted a similar study on $Z$. capricorni from New Zealand. Cayabyab \& Enríquez (2007) evaluated the photoacclimatory responses of $T$. testudinum plants to 3 distinct light treatments, comparing the daily variation in photochemical efficiency between basal and apical leaf sections.

Light availability is often regarded as the most important single parameter controlling seagrass distribution. Responses to light have been widely explored by many authors and from a number of different perspectives. A few studies have particularly addressed the relationships between photosynthesis and both depth- and turbidity-related light attenuation. Using the DivingPAM, Ralph et al. (1998) measured the in situ photosynthetic responses of Posidonia australis, P. sinuosa, Amphibolis antarctica, A. griffithii and Halophila ovalis from shallow Australian waters (0 to $6 \mathrm{~m}$ ), comparing them with laboratory measurements of the deeper growing $P$. angustifolia $(27 \mathrm{~m})$ and Thalassodendron pachyrhizu (46 m). Despite the use of 2 contrasting experimental approaches, the authors found significantly different patterns of photosynthetic behavior between shallow and deeper growing seagrasses. Schwarz \& Hellblom (2002) measured the photosynthetic light responses of Halophila stipulacea growing at different depths in the Red Sea. They found patterns of acclimation to distinct light environments, even though they only sampled a small depth range $(7$ to $30 \mathrm{~m}$ from a known 0 to $70 \mathrm{~m}$ total range). The same approach was used by Durako et al. (2003) to compare the photobiology of Halophila johnsonii and $H$. decipiens along a depth gradient in Florida, with the goal of explaining their relative depth distributions. Additionally, Collier et al. (2008) used Diving-PAM measurements to com- 
plement their physiological characterization of Australian Posidonia sinuosa along a very small vertical gradient down to $9 \mathrm{~m}$ depth. Comparing a broader spectrum of irradiance controlling factors, Campbell et al. $(2003,2007)$ used PAM fluorescence to evaluate the combination of light with other environmental factors on the distribution of several tropical seagrass species, comparing 4 major Australian habitats (estuarine, coastal, reef and deepwater).

Chlorophyll fluorescence has provided detailed descriptions of variation in seagrass photosynthetic performance at a number of spatial and temporal scales, essentially through the analysis of the quantum efficiency fluctuations. Photosynthetic responses to light have also been elucidated across a wide range of natural conditions of light quantity and quality.

PAM fluorescence has also been used to investigate inorganic carbon limitations to seagrass photosynthesis. Schwarz et al. (2000) used a Diving-PAM connected to a small chamber to evaluate in situ the inorganic carbon limitation to Halophila ovalis and Cymodocea serrulata photosynthesis. The underwater operating chamber was used to hold and isolate stillattached leaves, while permitting the addition of inorganic carbon, buffers or inhibitors to the leaf-adjacent medium. PAM fluorescence was also used by Enríquez \& Rodríguez-Román (2006) to analyze the photosynthetic response of Thalassia testudinum to carbon limitation, as influenced by water flow, in a set of laboratory experiments.

Chlorophyll fluorescence has proven to be a very useful tool in assessing the onset and recovery of numerous types of stress on seagrasses. As discussed above, the potential quantum yield of PSII, $F_{\mathrm{v}} / F_{\mathrm{m}}$, is a very useful indicator of stress conditions, and therefore is widely used in studies addressing a wide variety of stress situations. Desiccation is a major stressor in intertidal seagrasses. Hanelt et al. (1994) investigated low-tide stress in Thalassia hemprichii in South China and observed a midday depression in $F_{\mathrm{v}} / F_{\mathrm{m}}$, particularly when low tide occurred around solar noon, when desiccation effects were enhanced by high irradiances. The desiccation tolerance of several tropical intertidal seagrasses was evaluated by Björk et al. (1999) in Zanzibar. Interestingly, in that study, shallow intertidal species were overall more resistant to desiccation than deeper growing ones, leading the authors to conclude that desiccation tolerance is not the key factor in determining the vertical positioning of seagrass species in the intertidal zone, but rather their ability to withstand high irradiances. In a subsequent investigation in Zanzibar, Beer et al. (2006) compared the photosynthetic responses of $H$. ovalis, Cymodocea rotundata and Thalassia hemprichii in low-tide conditions, to find that the first species can only survive in monospecific tidal pools, given that the presence of the other 2 plants raises the $\mathrm{pH}$ above its compensation point.

The combined effects of desiccation and high temperatures were compared in Australian Posidonia australis and Amphibolis antarctica by Seddon \& Cheshire (2001). Thalassia hemprichii and Halodule uninervis from Taiwan were also compared by Lan et al. (2005) regarding their relative capacity to deal with both high irradiances and air exposure. The stress responses to high irradiance regimes have been mostly investigated in laboratory experiments, under well-controlled conditions, namely for Halophila ovalis (Ralph \& Burchett 1995, Ralph 1999a) and Zostera marina (Ralph et al. 2002). Figueroa et al. (2002) and Kunzelman et al. (2005) approached UV radiation stress by evaluating the responses of Posidonia oceanica and Halophila johnsonii to combinations of PAR with UV-A and/or UV-B, respectively. Other types of stress, whose effects have been evaluated through the PAM fluorescence technique, include thermal stress (Halophila ovalis, Ralph 1998; H. ovalis, Zostera capricorni, Syringodium isoetifolium, Campbell et al. 2006), osmotic stress $(H$. ovalis, Ralph 1998), herbicide toxicity (H. ovalis, $Z$. capricorni, Cymodocea serrulata, Haynes et al. 2000; H. ovalis, Ralph 2000), ammonium toxicity (Brun et al. 2008) or even a combination of factors such as temperature, light and salinity (Ralph 1999b).

Overall, PAM fluorometry has the advantage of being quick and non-intrusive, and since no enclosures are needed, it is particularly suited for in situ measurements. On the other hand, since respiration is ignored in the measurements (as only photosynthesis per se is measured), it is often impossible, or at least difficult, to compare such measurements with growth rates. Indeed, the most suitable questions to ask using PAM fluorometry are those concerning the photosynthetic light responses to the whole range of ambient parameters.

\section{Dissolved inorganic carbon uptake and $\mathrm{CO}_{2}$ fluxes}

Gas molecules, with the exception of those composed by 2 identical atoms, absorb radiation at extremely narrow bandwidths within the infrared region of the spectrum. $\mathrm{CO}_{2}$ has its main absorption peak at $\lambda=4.25 \mu \mathrm{m}$, with 3 secondary peaks at $2.66,2.77$ and $14.99 \mu \mathrm{m}$ (Long \& Hallgren 1985). Infrared gas analysis (IRGA) has therefore long been used to measure, with high accuracy, the evolution of $\mathrm{CO}_{2}$ exchanged in either the photosynthetic or respiratory process in terrestrial plants. A number of laboratory and portable gas analyzers are available, with varying configurations, from closed to semi-closed or even open systems, depending on the type of enclosure and air pathway 
(Long \& Hallgren 1985). Compared to the previously discussed methodologies, direct assessments of DIC uptake or $\mathrm{CO}_{2}$ flux measurements have rarely been used to estimate seagrass productivity; 4 distinct types of approaches have been described.

(1) Direct measurement of $\mathrm{CO}_{2}$ uptake by individual leaves, which are enclosed in a mini-cuvette with temperature and humidity control coupled to a portable infrared gas analyzer. Given the considerable extensions of intertidal seagrass meadows worldwide, and the array of information likely to be obtained in situ by these gas-exchange instruments (to which PAM fluorometry can also be coupled), it is surprising that only a few studies have used this approach (Leuschner \& Rees 1993, Leuschner et al. 1998, both with Zostera marina and $Z$. noltii). These highly controlled and accurate systems are, however, limited to intertidal habitats, as no adaptations are yet made to operate them underwater.

(2) DIC uptake at the community level has been mostly investigated using benthic incubations in closed chambers, where water is retained for a few hours. Initial and final DIC values are derived from variations in $\mathrm{pH}$ and alkalinity. As long incubation times are required for $\mathrm{pH}$ and alkalinity variations to occur, photosynthesis tends to saturate as Rubisco carboxylase activity decreases in response to the increasing $\mathrm{O}_{2}$ and decreasing $\mathrm{CO}_{2}$ concentrations within the chambers. No assessment has yet been made of how underestimated the carbon uptake measurements may be when using this technique. Using both transparent and dark chambers, the net community production and dark respiration are measured, providing an overall gross community production value. Studies based on this approach have been conducted on Zostera marina (Ibarra-Obando et al. 2004, Martin et al. 2005) and Posidonia oceanica communities (Barrón et al. 2006), complemented with $\mathrm{O}_{2}$ measurements.

(3) Silva et al. $(2005,2008)$ proposed a variation to the benthic incubation method by introducing water recirculation in the chambers and reducing the length of the incubations to minutes instead of hours. In this system, water from the chambers is recirculated by a peristaltic pump at the surface and flows through an equilibrator, which allows the partial pressure of $\mathrm{CO}_{2}$ $\left(\mathrm{pCO}_{2}\right)$ to be continuously monitored in the gas phase by an infrared gas analyzer. It is important that $\mathrm{pH}$ and alkalinity are measured before and after the incubation period, so as to provide an estimate of the total DIC flux. This method may also underestimate seagrass community production as $\mathrm{CO}_{2}$ uptake is being regenerated through carbonate equilibrium dynamics. Further discussion on the technical and analytical aspects of this method can be found in Abril (2009) and Silva \& Santos (2009).
(4) Air-sea $\mathrm{CO}_{2}$ fluxes have also been used to estimate the net community production of seagrassdominated coastal systems (Gazeau et al. 2005b). The air-sea $\mathrm{CO}_{2}$ flux is computed from the air-sea gradient of pCO2, the gas transfer velocity and the solubility coefficient of $\mathrm{CO}_{2}$. These fluxes can be determined either by following $\mathrm{pCO}_{2}$ evolution inside a floating bell system (Frankignoulle \& Distèche 1984) or by simultaneous measurements of both air and water $\mathrm{pCO}_{2}$ (Gazeau et al. 2005a, 2005b).

\section{Other methods}

Radioactively labelled carbon $\left({ }^{14} \mathrm{CO}_{2}\right.$ or $\left.\mathrm{H}^{14} \mathrm{CO}_{3}{ }^{-}\right)$ was one of the first (Beer et al. 2001) methods to determine $\mathrm{CO}_{2}$ uptake. The ${ }^{14} \mathrm{C}$ technique has mostly been used to investigate the mechanisms of carbon uptake in seagrasses (Beer \& Waisel 1979, Abel 1984) and its productivity (Williams \& McRoy 1982), but nowadays it is only rarely used.

New methodological possibilities are emerging, particularly those addressing large-scale evaluations of seagrass communitiy production. Hermand et al. (2001) and Hermand (2006) summarized the applicability of geo-acoustic inversion techniques to monitor photosynthetic $\mathrm{O}_{2}$ release in Posidonia oceanica meadows. The working principle, verified in this technique, was that the presence of non-dissolved gases in the leaves' aerenchyma and the production of $\mathrm{O}_{2}$ microbubbles sticking to the blade surface interfere with the impulse response of broad-band acoustic transmissions and can be correlated with whole-meadow photosynthetic activity. This method may provide continuous measurements of oxygen produced by seagrasses, and may be useful in monitoring seagrass productivity in large coastal areas. However, more developments of this technique, including calibration with more established methods and extrapolation to different seagrass species, are necessary.

The eddy correlation technique, used in terrestrial ecosystems, was adapted to aquatic environments by Berg et al. (2003). This technique determines the sediment-water fluxes of dissolved $\mathrm{O}_{2}$. The general operating principle lies in the simultaneous measurement of vertical water column velocity and $\mathrm{O}_{2}$ concentration at a point a given distance from the sediment surface (Berg \& Huettel 2008). This is a completely non-intrusive approach, capable of integrating considerable sediment areas (Berg et al. 2007). Although the technique's full potential is yet to be explored, it appears very promising, particularly in heterogeneous environments where its integrating capacity is an advantage. If used above seagrass meadows, this method may provide whole-ecosystem metabolism 
information. The first attempt to determine oxygen fluxes and ecosystem metabolism in seagrasses was made by Hume et al. (unpubl. data) in a Zostera marina community.

\section{CONCLUSIONS}

Table 1 summarizes the applications, advantages and disadvantages of the methods presented above to measure seagrass photosynthesis and production. In roughly 3 decades of research on seagrass photosynthesis, much information has been gained at different levels through the use of the various methodologies described here. $\mathrm{O}_{2}$ measurements, either by Winkler titration or by electrodes, provide accurate rates of net photosynthetic gas exchange in the light and respiration in darkness. However, limitations include the need to use enclosures which, invariably, alter natural irradiances and water flow conditions. $\mathrm{O}_{2}$ electrodes are also usually employed in the laboratory, with obvious limitations related to the removal of plants from their natural environments. Measurements of $\mathrm{CO}_{2}$ employing IRGA are much more sensitive than $\mathrm{O}_{2}$ measurements and thus require lower incubation times. While the IRGA technique is probably the best for measurements of intertidal seagrasses exposed to the air, its recent adaptation for measuring dissolved $\mathrm{CO}_{2}$ fluxes of underwater communities may underestimate them. Currently, the most employed method for in situ photosynthetic measurements is PAM fluorometry. It is fast (a measure of ETR can be obtained within $1 \mathrm{~s}$ ), and no enclosures are necessary. One major restriction is that respiration rates cannot be obtained by PAM fluorometry, and photosynthetic rates thus cannot be readily converted to production rates. However, this method is superb for investigating the stresses that impede photosynthesis (by measuring $F_{\mathrm{v}} / F_{\mathrm{m}}$ ) as well as for estimating photosynthetic responses to irradiance (including the use of RLCs). In the future, it is desirable that autonomous instruments that measure both chlorophyll fluorescence and $\mathrm{CO}_{2}$ gas exchange become available, so that many of the relevant seagrass photosynthetic parameters can be measured simultaneously over extended time periods.

Being rooted plants, seagrasses present the most complex physical structure among marine autotrophs, as plants simultaneously occupy 2 distinct environments, the water column and the sediment. The integrated physiology of above- and below-ground tissues adds a considerable degree of complexity to metabolic studies, namely in the accurate determination of $\mathrm{CO}_{2}$ fixation and $\mathrm{O}_{2}$ production rates. In fact, although it may represent more than half of the whole-plant $\mathrm{O}_{2}$ consumption (Fourqurean \& Zieman 1991), root- rhizome respiration is rather difficult to measure in $s i t u$, and highly unrealistic if measured in laboratory conditions. On the other hand, a significant portion of the photosynthetically evolved $\mathrm{O}_{2}$ is conveyed down from the leaves to the below-ground tissues in order to support respiration and also to maintain some degree of aerobiosis in the rhizosphere, which is often surrounded by anoxic sediment (Larkum et al. 1989). In this context, despite several laboratory studies (Smith et al. 1984, Connell et al. 1999), it was Greve et al. (2003) and Binzer et al. (2005) who firstly provided accurate in situ measurements of $\mathrm{O}_{2}$ leakage by seagrass roots and rhizomes, using $\mathrm{O}_{2}$ micro-electrodes. $\mathrm{O}_{2}$ optodes (Glud 2008) added a second dimension to these measurements. Whereas respiration measurements at the plant level are fairly simple in the laboratory, their extension to the community level has low value. On the other hand, community measurements still present a great number of uncertainty factors (outlined in Middelburg et al. 2005). One of the paths to explore further in seagrass photosynthetic production research is the assessment of the metabolic contribution of other autotrophic and heterotrophic components of seagrass communities. Process discrimination and separate metabolic evaluations are essential, in particular sediment respiration, to avoid considering the sediment as just a black box within the community. This will help obtain accurate metabolic budgets for seagrass communities, thus closing the gap between gross and net primary production.

This review of the published literature on seagrass photosynthesis, although oriented to methodological aspects, also provided an assessment of the status of seagrass photosynthesis research. We agree with a recent review of the impact of light limitation on seagrasses (Ralph et al. 2007): although a great deal is known on seagrass ecophysiology, much information is still missing, including many fundamental photobiological data. Our analysis of the literature revealed, for example, that even though seagrasses have a wide depth distribution gradient, down to 50-70 m (den Hartog 1970), hardly any work has been done on deep populations. This is a major gap in knowledge, especially given the importance of understanding the biology of plants living in extreme environments and taking into account that seagrass declines worldwide are attributed largely to reductions in light availability (Ralph et al. 2007 and references therein). The availability of underwater instruments such as the DivingPAM, and the fact that such deep populations are within the depth range for technical diving, provides an opportunity for narrowing these gaps in knowledge.

With the development of the new large-scale assessment techniques described above, research questions 
Table 1. Applications, advantages and disadvantages of the most common methods used in seagrass photosynthesis and community metabolism studies

\begin{tabular}{|c|c|c|c|}
\hline Method & Applications & Advantages & Disadvantages \\
\hline $\mathrm{O}_{2}$ titration (Winkler) & $\begin{array}{l}\text { - Photosynthesis and dark } \\
\text { respiration of whole plants } \\
\text { or leaf cuts incubated in } \\
\text { bottles (laboratory or in } \\
\text { situ) } \\
\text { - } \mathrm{O}_{2} \text { analysis of water } \\
\text { samples from benthic } \\
\text { chambers (field) }\end{array}$ & $\begin{array}{l}\text { - High accuracy } \\
\text { - Low price }\end{array}$ & $\begin{array}{l}\text { - Intrusive (if plants are } \\
\text { incubated in bottles) } \\
\text { - Problems related to } \\
\text { containment in closed } \\
\text { chambers } \\
\text { - Initial and final } \mathrm{O}_{2} \\
\text { concentrations only } \\
\text { - Cumbersome }\end{array}$ \\
\hline $\begin{array}{l}\mathrm{O}_{2} \text { electrodes coupled } \\
\text { to small reaction } \\
\text { chambers }\end{array}$ & $\begin{array}{l}\text { - Photosynthesis and dark } \\
\text { respiration of leaf cuts } \\
\text { (laboratory) }\end{array}$ & $\begin{array}{l}\text { - High resolution } \\
\text { - High accuracy } \\
\text { - Continuous } \mathrm{O}_{2} \text { measure- } \\
\text { ments } \\
\text { - Highly controlled condi- } \\
\text { tions } \\
\text { - Possibility to manipulate } \\
\text { the incubation medium }\end{array}$ & $\begin{array}{l}\text { - Intrusive } \\
\text { - Highly artificial } \\
\text { - Spectral quality of arti- } \\
\quad \text { ficial light sources }\end{array}$ \\
\hline $\mathrm{O}_{2}$ microelectrodes & $\begin{array}{l}\text { - } \mathrm{O}_{2} \text { consumption by below- } \\
\text { ground tissues (in situ) } \\
\text { - } \mathrm{O}_{2} \text { leakage into the rhizo- } \\
\text { sphere (in situ) } \\
\text { - } \mathrm{O}_{2} \text { production or con- } \\
\text { sumption in custom-made } \\
\text { chambers } \\
\text { - Used in the eddy correla- } \\
\text { tion technique (in situ) }\end{array}$ & $\begin{array}{l}\text { - Not very intrusive (small } \\
\text { diameter electrodes) } \\
\text { - Fast response time } \\
\text { - Positioning possibilities }\end{array}$ & $\begin{array}{l}\text { - Small spatial resolution } \\
\text { - Fragile in field condi- } \\
\text { tions }\end{array}$ \\
\hline $\mathrm{O}_{2}$ optodes & $\begin{array}{l}\text { - } \mathrm{O}_{2} \text { mapping of seagrass } \\
\text { rhizosphere (in situ) }\end{array}$ & $\begin{array}{l}\text { - Not very intrusive } \\
\text { - 2-dimensional measure- } \\
\text { ments } \\
\text { - Very sensitive at low } \mathrm{O}_{2} \\
\text { concentrations } \\
\text { - Does not consume } \mathrm{O}_{2} \\
\text { - Long-term stability }\end{array}$ & $\begin{array}{l}\text { - Slower response than } \\
\text { microelectrodes } \\
\text { - Technique still under } \\
\text { development }\end{array}$ \\
\hline PAM fluorescence & $\begin{array}{l}\text { - In situ and laboratory } \\
\text { measurements of photo- } \\
\text { synthetic efficiency at the } \\
\text { plant level }\end{array}$ & $\begin{array}{l}\text { - Non-intrusive } \\
\text { - Portability } \\
\text { - Autonomous underwater } \\
\text { equipment } \\
\text { - Possibility of continuous } \\
\text { measurements }\end{array}$ & $\begin{array}{l}\text { - Measures light reactions } \\
\text { only } \\
\text { - Does not allow respira- } \\
\text { tion measurements or } \\
\text { thus production esti- } \\
\text { mates }\end{array}$ \\
\hline $\mathrm{CO}_{2}$ evolution & $\begin{array}{l}\text { - In situ measurements of } \\
\text { community uptake and } \\
\text { release of } \mathrm{CO}_{2} \text {, in incu- } \\
\text { bation chambers }\end{array}$ & $\begin{array}{l}\text { - Non-intrusive } \\
\text { - Integration of whole- } \\
\text { community metabolism } \\
\text { - Highly reliable in air- } \\
\text { exposed conditions }\end{array}$ & $\begin{array}{l}\text { - Possibility of underesti- } \\
\text { mating } \mathrm{CO}_{2} \text { uptake in } \\
\text { underwater conditions } \\
\text { - Problems related to } \\
\text { containment in closed } \\
\text { chambers }\end{array}$ \\
\hline Geo-acoustics & $\begin{array}{l}\text { - In situ large-scale estima- } \\
\text { tion of community } \mathrm{O}_{2} \text { prod- } \\
\text { uction }\end{array}$ & $\begin{array}{l}\text { - Large-scale application, } \\
\text { suitable for ecosystem } \\
\text { level studies } \\
\text { - Continuous measurements }\end{array}$ & $\begin{array}{l}\text { - Underdeveloped } \\
\text { technique }\end{array}$ \\
\hline Eddy correlation & $\begin{array}{l}\text { - In situ sediment-water } \\
\text { fluxes of dissolved } \mathrm{O}_{2} \\
\text { - Community level } \mathrm{O}_{2} \\
\text { fluxes metabolic studies }\end{array}$ & $\begin{array}{l}\text { - Non-intrusive } \\
\text { - Autonomous underwater } \\
\text { equipment } \\
\text { - Good surface integrating } \\
\text { capacity } \\
\text { - Continuous measurements }\end{array}$ & $\begin{array}{l}\text { - Underdeveloped } \\
\text { technique }\end{array}$ \\
\hline
\end{tabular}


pertaining to seagrass meadows as global $\mathrm{CO}_{2}$ sinks may be answered in the coming years. The effects of global warming on seagrass metabolism also require further research, particularly concerning the effects of respiration. Additionally, ocean acidification with the concomitant $\mathrm{CO}_{2}$ increase is expected to positively affect seagrass photosynthetic rates, but experimental studies are scarce (Palacios \& Zimmermann 2007). Another interesting aspect to explore related to ocean acidification is the interaction between seagrass photosynthesis and the calcification rates of other organisms within the community (e.g. Semesi et al. 2009). We thus expect future research to bridge the gap between the photosynthetic behaviour of individual plants and the various aspects of community-level metabolism.

Acknowledgements. This review was presented as a keynote lecture at the 8th International Workshop of the Group for Aquatic Primary Productivity (GAP) and Batsheva de Rothschild Seminar on Gross and Net Primary Productivity, held at the Interuniversity Institute for Marine Sciences, Eilat, Israel, in April 2008. We thank the Batsheva de Rothschild Foundation, Bar Ilan University, the Moshe Shilo Center for Marine Biogeochemistry and the staff of the Interuniversity Institute for funding and logistic support. J.S. thanks the organizers of the workshop, in particular I. Berman-Frank, for the opportunity to give this talk and for the wonderful welcome in Eilat.

\section{LITERATURE CITED}

Abel KM (1984) Inorganic carbon source for photosynthesis in the seagrass Thalassia hemprichii (Ehrenb) Aschers. Plant Physiol 76:776-781

Abril G (2009) Comments on: 'Underwater measurements of carbon dioxide evolution in marine plant communities: a new method' by J. Silva and R. Santos [Estuarine, Coastal and Shelf Science 78(2008) 827-830]. Estuar Coast Shelf Sci 82:357-360

Alcoverro T, Manzanera M, Romero J (1998) Seasonal and age-dependent variability of Posidonia oceanica (L.) Delile photosynthetic parameters. J Exp Mar Biol Ecol 230:1-13

Alcoverro T, Manzanera M, Romero J (2001) Annual metabolic carbon balance of the seagrass Posidonia oceanica: the importance of carbohydrate reserves. Mar Ecol Prog Ser 211:105-116

Asada K (1999) The water-water cycle in chloroplasts: scavenging of active oxygens and dissipation of excess photons. Annu Rev Plant Physiol Plant Mol Biol 50:601-639

Barrón C, Marbá N, Terrados J, Kennedy H, Duarte CM (2004) Community metabolism and carbon budget along a gradient of seagrass (Cymodocea nodosa) colonization. Limnol Oceanogr 49:1642-1651

Barrón C, Duarte CM, Frankignoulle M, Borges AV (2006) Organic carbon metabolism and carbonate dynamics in a Mediterranean seagrass (Posidonia oceanica) meadow. Estuar Coast 29:417-426

Beer S (1989) Photosynthesis and photorespiration in marine angiosperms. Aquat Bot 34:153-166

Beer S, Björk M (2000) Measuring rates of photosynthesis of two tropical seagrasses by pulse amplitude modulated (PAM) fluorometry. Aquat Bot 66:69-76

Beer S, Koch E (1996) Photosynthesis of marine macroalgae and seagrasses in globally changing $\mathrm{CO}_{2}$ environments.
Mar Ecol Prog Ser 141:199-204

Beer S, Rehnberg J (1997) The acquisition of inorganic carbon by the seagrass Zostera marina. Aquat Bot 56:277-283

Beer S, Waisel Y (1979) Some photosynthetic carbon fixation properties of seagrasses. Aquat Bot 7:129-138

- Beer S, Waisel Y (1982) Effects of light and pressure on photosynthesis in two seagrasses. Aquat Bot 13:331-337

Beer S, Vilenkin B, Weil A, Veste M, Susel L, Eschel A (1998) Measuring photosynthetic rates in seagrass by pulse amplitude modulated (PAM) fluorometry. Mar Ecol Prog Ser 174:293-300

Beer S, Björk M, Gademann R, Ralph P (2001) Measurements of photosynthetic rates in seagrasses. In: Short FT, Coles RG (eds) Global seagrass research methods. Elsevier, Amsterdam, p 183-198

Beer S, Bjork M, Hellblom F, Axelsson L (2002) Inorganic carbon utilization in marine angiosperms (seagrasses). Funct Plant Biol 29:349-354

> Beer S, Mtolera M, Lyimo T, Bjork M (2006) The photosynthetic performance of the tropical seagrass Halophila ovalis in the upper intertidal. Aquat Bot 84:367-371

Belshe EF, Durako MJ, Blum JE (2008) Diurnal light curves and landscape-scale variation in photosynthetic characteristics of Thalassia testudinum in Florida Bay. Aquat Bot 89:16-22

Berg P, Huettel M (2008) Monitoring the seafloor using the noninvasive eddy correlation technique: integrated benthic exchange dynamics. Oceanography 21:164-167

Berg P, Røy H, Janssen F, Meyer V, Jørgensen BB, Huettel M, De Beer D (2003) $\mathrm{O}_{2}$ uptake by aquatic sediments measured with a novel non-invasive eddy correlation technique. Mar Ecol Prog Ser 261:75-83

Berg P, Røy H, Wiberg PL (2007) Eddy correlation flux measurements: the sediment surface area that contributes to the flux. Limnol Oceanogr 52:1672-1684

Bintz JC, Nixon SW (2001) Responses of eelgrass Zostera marina seedlings to reduced light. Mar Ecol Prog Ser 223: 133-141

Binzer T, Borum J, Pedersen O (2005) Flow velocity affects internal oxygen conditions in the seagrass Cymodocea nodosa. Aquat Bot 83:239-247

Björk M, Weil A, Semesi S, Beer S (1997) Photosynthetic utilisation of inorganic carbon by seagrasses from Zanzibar, East Africa. Mar Biol 129:363-366

Björk M, Uku J, Weil A, Beer S (1999) Photosynthetic tolerances to desiccation of tropical intertidal seagrasses. Mar Ecol Prog Ser 191:121-126

> Brun FG, Olivé I, Malta EJ, Vergara JJ, Hernandez I, PérezLloréns JL (2008) Increased vulnerability of Zostera noltii to stress caused by low light and elevated ammonium levels under phosphate deficiency. Mar Ecol Prog Ser 365:67-75

Buschmann C, Lichtenthaler HK (1988) Complete fluorescence emission spectra determined during the induction kinetic using a diode-array detector. In: Lichtenthaler HK (ed) Applications of chlorophyll fluorescence. Kluwer Academic Press, Dordrecht, p 77-84

Cabello-Pasini A, Alberte RS (1997) Seasonal patterns of photosynthesis and light-independent carbon fixation in marine macrophytes. J Phycol 33:321-329

> Cabello-Pasini A, Lara-Turrent C, Zimmerman RC (2002) Effect of storms on photosynthesis, carbohydrate content and survival of eelgrass populations from a coastal lagoon and the adjacent open ocean. Aquat Bot 74:149-164

Campbell S, Miller C, Steven A, Stephens A (2003) Photosynthetic responses of two temperate seagrasses across a water quality gradient using chlorophyll fluorescence. J Exp Mar Biol Ecol 291:57-78

Campbell SJ, McKenzie LJ, Kerville SP (2006) Photosynthetic 
responses of seven tropical seagrasses to elevated seawater temperature. J Exp Mar Biol Ecol 330:455-468

Campbell SJ, McKenzie LJ, Kerville SP, Bite JS (2007) Patterns in tropical seagrass photosynthesis in relation to light, depth and habitat. Estuar Coast Shelf Sci 73:551-562

Cayabyab NM, Enríquez S (2007) Leaf photoacclimatory responses of the tropical seagrass Thalassia testudinum under mesocosm conditions: a mechanistic scaling-up study. New Phytol 176:108-123

Collier CJ, Lavery PS, Ralph PJ, Masini RJ (2008) Physiological characteristics of the seagrass Posidonia sinuosa along a depth-related gradient of light availability. Mar Ecol Prog Ser 353:65-79

Connell EL, Colmer TD, Walker DI (1999) Radial oxygen loss from intact roots of Halophila ovalis as a function of distance behind the root tip and shoot illumination. Aquat Bot 63:219-228

> Costanza R, d'Arge R, de Groot R, Farber S and others (1997) The value of the world's ecosystems services and natural capital. Nature 387:253-260

Dawson SP, Dennison WC (1996) Effects of ultraviolet and photosynthetically active radiation on five seagrass species. Mar Biol 125:629-639

den Hartog C (1970) Seagrasses of the world. North-Holland Publishing, Amsterdam

> Dennison WC, Alberte RS (1982) Photosynthetic responses of Zostera marina L (eelgrass) to in situ manipulations of light intensity. Oecologia 55:137-144

- Drew EA (1978) Factors affecting photosynthesis and its seasonal variation in the seagrasses Cymodocea nodosa (Ucria) Aschers, and Posidonia oceanica (L.) Delile in the Mediterranean. J Exp Mar Biol Ecol 31:173-194

$>$ Drew EA (1979) Physiological aspects of primary production in seagrasses. Aquat Bot 7:139-150

> Drew EA, Robertson WAA (1974) A simple field version of the Winkler determination of dissolved oxygen. New Phytol 73:793-796

Duarte CM, Cebrián J (1996) The fate of marine autotrophic production. Limnol Oceanogr 41:1758-1766

Duarte CM, Chiscano CL (1999) Seagrass biomass and production: a reassessment. Aquat Bot 65:159-174

Dunton KH, Tomasko DA (1994) In situ photosynthesis in the seagrass Halodule wrightii in a hypersaline subtropical lagoon. Mar Ecol Prog Ser 107:281-293

Durako MJ (1993) Photosynthetic utilization of $\mathrm{CO}_{2}$ and $\mathrm{HCO}_{3}{ }^{-}$in Thalassia testudinum (Hydrocharitaceae). Mar Biol 115:373-380

> Durako MJ (2007) Leaf optical properties and photosynthetic leaf absorptances in several Australian seagrasses. Aquat Bot 87:83-89

> Durako MJ, Kunzelman JI (2002) Photosynthetic characteristics of Thalassia testudinum measured in situ by pulseamplitude modulated (PAM) fluorometry: methodological and scale-based considerations. Aquat Bot 73:173-185

Durako MJ, Kunzelman JI, Kenworthy WJ, Hammerstrom KK (2003) Depth-related variability in the photobiology of two populations of Halophila johnsonii and Halophila decipiens. Mar Biol 142:1219-1228

Enríquez S, Rodríguez-Román A (2006) Effect of water flow on the photosynthesis of three marine macrophytes from a fringing-reef lagoon. Mar Ecol Prog Ser 323:119-132

Enríquez S, Duarte CM, Sand-Jensen K (1995) Patterns in the photosynthetic metabolism of Mediterranean macrophytes. Mar Ecol Prog Ser 119:243-252

Enríquez S, Merino M, Iglesias-Prieto R (2002) Variations in the photosynthetic performance along the leaves of the tropical seagrass Thalassia testudinum. Mar Biol 140: 891-900
Evans A, Webb K, Penhale P (1986) Photosynthetic temperature acclimation in two coexisting seagrasses, Zostera marina L. and Ruppia maritima L. Aquat Bot 24:185-197

Figueroa FL, Jiménez C, Viñegla B, Pérez-Rodriguez E and others (2002) Effects of solar UV radiation on photosynthesis of the marine angiosperm Posidonia oceanica from southern Spain. Mar Ecol Prog Ser 230:59-70

> Flexas J, Medrano H (2002) Energy dissipation in $\mathrm{C}_{3}$ plants under drought. Funct Plant Biol 29:1209-1215

Fourqurean JW, Zieman JC (1991) Photosynthesis, respiration and whole plant carbon budget of the seagrass Thalassia testudinum. Mar Ecol Prog Ser 69:161-170

Frankignoulle $\mathrm{M}$, Distèche A (1984) $\mathrm{CO}_{2}$ chemistry in the water columm above a Posidonia seagrass bed and related air-sea exchanges. Oceanol Acta 7:209-219

Franklin LA, Badger MR (2001) A comparison of photosynthetic electron transport rates in macroalgae measured by pulse amplitude modulated chlorophyll fluorometry and mass spectrometry. J Phycol 37:756-767

Frederiksen MS, Glud RN (2006) Oxygen dynamics in the rhizosphere of Zostera marina: a 2-dimensional planar optode study. Limnol Oceanogr 51:1072-1083

> Gazeau F, Borges A, Barrón C, Duarte CM and others (2005a) Net ecosystem metabolism in a micro-tidal estuary (Randers Fjord, Denmark): evaluation of methods. Mar Ecol Prog Ser 301:23-41

Gazeau F, Duarte CM, Gattuso JP, Barrón C and others (2005b) Whole-system metabolism and $\mathrm{CO}_{2}$ fluxes in a Mediterranean Bay dominated by seagrass beds (Palma Bay, NW Mediterranean). Biogeosciences 2:43-60

Genty B, Briantais J, Baker N (1989) The relationship between the quantum yield of photosynthetic electron transport and quenching of chlorophyll fluorescence. Biochim Biophys Acta 990:87-92

Glud RN (2008) Oxygen dynamics of marine sediments. Mar Biol Res 4:243-289

Glud RN, Tengberg A, Kuhl M, Hall POJ, Klimant I, Host G (2001) An in situ instrument for planar $\mathrm{O}_{2}$ optode measurements at benthic interfaces. Limnol Oceanogr 46: 2073-2080

Grasshoff K, Ehrhardt M, Kremling K (1983) Methods of seawater analysis. Verlag Chemie, Weinheim

Greve TM, Borum J, Pedersen O (2003) Meristematic oxygen variability in eelgrass (Zostera marina). Limnol Oceanogr 48:210-216

Grzymski J, Johnsen G, Sakshaug E (1997) The significance of intracellular self-shading on the bio-optical properties of brown, red and green macroalgae. J Phycol 33:408-414

Hanelt D, Li J, Nultsch W (1994) Tidal dependence of photoinhibition of photosynthesis in marine macrophytes of the South China Sea. Bot Acta 107:66-72

- Haynes D, Ralph P, Pranges J, Dennison B (2000) The impact of the herbicide diuron on photosynthesis in 3 species of tropical seagrass. Mar Pollut Bull 41:288-293

Hellblom F, Beer S, Bjork M, Axelsson L (2001) A buffer sensitive inorganic carbon utilisation system in Zostera marina. Aquat Bot 69:55-62

Hermand JP (2006) Continuous acoustic monitoring of physiological and environmental processes in seagrass prairies with focus on photosynthesis. In: Caiti A, Chapman NR, Hermand JP, Jesus S (eds) Acoustic sensing techniques for the shallow water environment: inversion methods and experiments. Springer, Dordrecht, p 183-196

Hermand JP, Nascetti P, Cinelli F (2001) Inverse acoustical determination of photosynthetic oxygen productivity of Posidonia seagrass. In: Caiti A, Hermand JP, Jesus S, Porter MB (eds) Proc Workshop Exp Acoustic Inversion Meth Explor Shallow Water Environ. Kluwer Academic 
Press, Dordrecht, p 125-144

Herzka SZ, Dunton KH (1997) Seasonal photosynthetic patterns of the seagrass Thalassia testidinum in the western Gulf of Mexico. Mar Ecol Prog Ser 152:103-117

> Ibarra-Obando SE, Smith SV, Poumian-Tapia M, CamachoIbar V, Carriquiry JD, Montes-Hugo M (2004) Benthic metabolism in San Quintin Bay, Baja California, Mexico. Mar Ecol Prog Ser 283:99-112

> Invers O, Romero J, Perez M (1997) Effects of pH on seagrass photosynthesis: a laboratory and field assessment. Aquat Bot 59:185-194

Invers O, Perez M, Romero J (1999) Bicarbonate utilization in seagrass photosynthesis: role of carbonic anhydrase in Posidonia oceanica (L.) Delile and Cymodocea nodosa (Ucria) Ascherson. J Exp Mar Biol Ecol 235:125-133

> Invers O, Zimmerman RC, Alberte RS, Pérez M, Romero J (2001) Inorganic carbon sources for seagrass photosynthesis: an experimental evaluation of bicarbonate use in species inhabiting temperate waters. J Exp Mar Biol Ecol 265: 203-217

James PL, Larkum AWD (1996) Photosynthetic inorganic carbon acquisition of Posidonia australis. Aquat Bot 55: 149-157

Jensen SI, Kühl M, Glud RN, Jørgensen LB, Priemé A (2005) Oxic microzones and radial oxygen loss from roots of Zostera marina. Mar Ecol Prog Ser 293:49-58

Jones HG (1994) Plants and microclimate. Cambridge University Press, New York

Kaldy JE, Dunton KH (1999) Ontogenetic photosynthetic changes, dispersal and survival of Thalassia testudinum (turtle grass) seedlings in a sub-tropical lagoon. J Exp Mar Biol Ecol 240:193-212

> Kerr EA, Strother S (1985) Effects of irradiance, temperature and salinity on photosynthesis of Zostera muelleri. Aquat Bot 23:177-183

Koch EW (1994) Hydrodynamics, diffusion-boundary layers and photosynthesis of the seagrasses Thalassia testudinum and Cymodocea nodosa. Mar Biol 118:767-776

Koch EW, Dawes CJ (1991) Ecotypic differentiation in populations of Ruppia maritima L. germinated from seeds and cultured under algae-free laboratory conditions. J Exp Mar Biol Ecol 152:145-159

Kühl M, Polerecky L (2008) Functional and structural imaging of phototrophic microbial communities and symbioses. Aquat Microb Ecol 53:99-118

Kunzelman JI, Durako MJ, Kenworthy WJ, Stapleton A, Wright JLC (2005) Irradiance-induced changes in the photobiology of Halophila johnsonii. Mar Biol 148:241-250

Lan CY, Kao WY, Lin HJ, Shao KT (2005) Measurement of chlorophyll fluorescence reveals mechanisms for habitat niche separation of the intertidal seagrasses Thalassia hemprichii and Halodule uninervis. Mar Biol 148:25-34

Larkum AWD, Roberts G, Kuo J, Strother S (1989) Gaseous movement in seagrasses. In: Larkum AWD, McComb AJ, Shepherd SA (eds) Biology of seagrasses. Elsevier, Amsterdam, p 686-722

> Lee KS, Park SR, Kim YK (2007) Effects of irradiance, temperature, and nutrients on growth dynamics of seagrasses: a review. J Exp Mar Biol Ecol 350:144-175

Leuschner C, Rees U (1993) $\mathrm{CO}_{2}$ gas exchange of two intertidal seagrass species, Zostera marina L. and Zostera noltii Hornem., during emersion. Aquat Bot 45:53-62

> Leuschner C, Landwehr S, Mehlig U (1998) Limitation of carbon assimilation of intertidal Zostera noltii and $Z$. marina by desiccation at low tide. Aquat Bot 62:171-176

Long SP, Hallgren JE (1985) Measurement of $\mathrm{CO}_{2}$ assimilation by plants in the field and the laboratory. In: Coombs J, Hall DO, Long SP, Scurlock JMO (eds) Techniques in bio- productivity and photosynthesis. Pergamon Press, Oxford, p 62-94

Major KM, Dunton KH (2000) Photosynthetic performance in Syringodium filiforme: seasonal variation in lightharvesting characteristics. Aquat Bot 68:249-264

Makino A, Miyake C, Yokota A (2002) Physiological functions of the water-water cycle (Mehler reaction) and the cyclic electron flow around PSI in rice leaves. Plant Cell Physiol 43:1017-1026

Martin S, Clavier J, Guarini JM, Chauvaud L and others (2005) Comparison of Zostera marina and maerl community metabolism. Aquat Bot 83:161-174

Masini RJ, Manning CR (1997) The photosynthetic responses to irradiance and temperature of four meadow-forming seagrasses. Aquat Bot 58:21-36

Masini RJ, Cary JL, Simpson CJ, McComb AJ (1995) Effects of light and temperature on the photosynthesis of temperate meadow-forming seagrasses in Western Australia. Aquat Bot 49:239-254

> Mercado JM, Niell FX, Silva J, Santos R (2003) Use of light and inorganic carbon acquisition by two morphotypes of Zostera noltii Hornem. J Exp Mar Biol Ecol 297:71-84

Middelburg JJ, Duarte CM, Gattuso JP (2005) Respiration in coastal benthic communities. In: Williams PJB, del Giorgio PA (eds) Respiration in aquatic ecosystems. Oxford University Press, New York, p 206-224

Miller HL III, Dunton KH (2007) Stable isotope $\left({ }^{13} \mathrm{C}\right)$ and $\mathrm{O}_{2}$ micro-optode alternatives for measuring photosynthesis in seaweeds. Mar Ecol Prog Ser 329:85-97

Millhouse J, Strother S (1986) The effect of pH on the inorganic carbon source for photosynthesis in the seagrass Zostera muelleri Irmisch ex Aschers. Aquat Bot 24:199-209

Olesen B, Enriquez S, Duarte CM, Sand-Jensen K (2002) Depth-acclimation of photosynthesis, morphology and demography of Posidonia oceanica and Cymodocea nodosa in the Spanish Mediterranean Sea. Mar Ecol Prog Ser 236:89-97

> Palacios SL, Zimmermann RC (2007) Response of eelgrass Zostera marina to $\mathrm{CO}_{2}$ enrichment: possible impacts of climate change and potential for remediation of coastal habitats. Mar Ecol Prog Ser 344:1-13

Peralta G, Pérez-Lloréns JL, Hernández I, Brun F and others (2000) Morphological and physiological differences between two morphotypes of Zostera noltii Hornem. from the south-western Iberian Peninsula. Helgol Mar Res 54: $80-86$

Peralta G, Brun FG, Hernandez I, Vergara JJ, Perez-Llorens JL (2005) Morphometric variations as acclimation mechanisms in Zostera noltii beds. Estuar Coast Shelf Sci 64: $347-356$

Pérez M, Romero J (1992) Photosynthetic response to light and temperature of the seagrass Cymodocea nodosa and the prediction of its seasonality. Aquat Bot 43:51-62

Plus M, Deslous-Paoli JM, Auby I, Dagault F (2001) Factors influencing primary production of seagrass beds (Zostera noltii Hornem.) in the Thau Lagoon (French Mediterranean coast). J Exp Mar Biol Ecol 259:63-84

Ralph PJ (1996) Diurnal photosynthetic patterns of Halophila ovalis (R. Br.) Hook. f. In: Kuo J, Philips RC, Walker DI, Kirkman H (eds) Seagrass biology: Proc Int Workshop, Rottnest Island, Western Australia, 25-29 Jan 1996, p 197-202

> Ralph PJ (1998) Photosynthetic responses of Halophila ovalis (R. Br.) Hook. $f$. to osmotic stress. J Exp Mar Biol Ecol 227: 203-220

> Ralph PJ (1999a) Light-induced photoinhibitory stress responses of laboratory-cultured Halophila ovalis. Bot Mar 42:11-22

Ralph PJ (1999b) Photosynthetic response of Halophila ovalis 
(R. Br.) Hook. $f$. to combined environmental stress. Aquat Bot 65:83-96

Ralph PJ (2000) Herbicide toxicity of Halophila ovalis assessed by chlorophyll fluorescence. Aquat Bot 66:141-152

Ralph PJ, Burchett MD (1995) Photosynthetic response of the seagrass Halophila ovalis (R. Br.) Hook. $f$. to high irradiance stress, using chlorophyll a fluorescence. Aquat Bot 51:55-66

Ralph PJ, Gademann R (1999) Photosynthesis of the seagrass Posidonia australis Hook. f. and associated epiphytes, measured by in situ fluorescence analysis. In: Walker DI, Wells FE (eds) The seagrass flora and fauna of Rottnest Island, Western Australia. Western Australian Museum, Perth, p 63-71

Ralph PJ, Gademann R (2005) Rapid light curves: a powerful tool to assess photosynthetic activity. Aquat Bot 82: 222-237

Ralph PJ, Gademann R, Dennison WC (1998) In situ seagrass photosynthesis measured using a submersible, pulseamplitude modulated fluorometer. Mar Biol 132:367-373

Ralph PJ, Polk SM, Moore KA, Orth RJ, Smith WO (2002) Operation of the xanthophyll cycle in the seagrass Zostera marina in response to variable irradiance. J Exp Mar Biol Ecol 271:189-207

Ralph PJ, Durako MJ, Enriquez S, Collier CJ, Doblin MA (2007) Impact of light limitation on seagrasses. J Exp Mar Biol Ecol 350:176-193

Ramírez-García P, Lot A, Duarte CM, Terrados J, Agawin NSR (1998) Bathymetric distribution, biomass and growth dynamics of intertidal Phyllospadix scouleri and Phyllospadix torreyi in Baja California (Mexico). Mar Ecol Prog Ser 173:13-23

Ruiz JM, Romero J (2001) Effects of in situ experimental shading on the Mediterranean seagrass Posidonia oceanica. Mar Ecol Prog Ser 215:107-120

Runcie JW, Durako MJ (2004) Among-shoot variability and leaf-specific absorptance characteristics affect diel estimates of in situ electron transport of Posidonia australis. Aquat Bot 80:209-220

Runcie JW, Riddle MJ (2004) Measuring variability in chlorophyll-fluorescence derived photosynthetic parameters in situ with a programmable multi-channel fluorometer. Funct Plant Biol 31:559-562

Runcie JW, Paulo D, Santos R, Sharon Y, Beer S, Silva J (2009) Photosynthetic responses of Halophila stipulacea to a light gradient. I. In situ energy partitioning of non-photochemical quenching. Aquat Biol 7:143-152

Saroussi S, Beer S (2007) Alpha and quantum yield of aquatic plants derived from PAM fluorometry: uses and misuses. Aquat Bot 86:89-92

Schreiber U, Bilger W, Klughammer C, Neubauer C (1988) Application of the PAM fluorometer in stress detection. In: Lichtenthaler HK (ed) Applications of chlorophyll fluorescence in photosynthesis research, stress physiology, hydrobiology and remote sensing. Kluwer Academic Press, Dordrecht, p 151-155

Schreiber U, Bilger W, Neubauer C (1995) Chlorophyll fluorescence as a nonintrusive indicator for rapid assessment of in vivo photosynthesis. In: Schulze ED, Caldwell MM (eds) Ecophysiology of photosynthesis. Springer-Verlag, Berlin, p 49-70

Schreiber U, Bilger W, Hormann H, Neubauer C (1998) Chlorophyll fluorescence as a dioganostic tool: basics and some aspects of practical relevance. In: Raghavendra AS (ed) Photosynthesis: a comprehensive treatise. Cambridge University Press, Cambridge, p 320-336

Schwarz AM, Hellblom F (2002) The photosynthetic light response of Halophila stipulacea growing along a depth gradient in the Gulf of Aqaba, the Red Sea. Aquat Bot 74: 263-272

Schwarz AM, Björk M, Buluda T, Mtolera M, Beer S (2000) Photosynthetic utilisation of carbon and light by two tropical seagrass species as measured in situ. Mar Biol 137:755-761

Seddon S, Cheshire AC (2001) Photosynthetic response of Amphibolis antarctica and Posidonia australis to temperature and desiccation using chlorophyll fluorescence. Mar Ecol Prog Ser 220:119-130

Semesi IS, Beer S, Björk M (2009) Seagrass photosynthesis controls rates of calcification and photosynthesis of calcareous macroalgae in a tropical seagrass meadow. Mar Ecol Prog Ser 382:41-47

Sharon Y, Beer S (2008) Diurnal movements of chloroplasts in Halophila stipulacea and their effect on PAM fluorometric measurements of photosynthetic rates. Aquat Bot 88: $273-276$

Silva J, Santos R (2003) Daily variation patterns in seagrass photosynthesis along a vertical gradient. Mar Ecol Prog Ser 257:37-44

Silva J, Santos R (2004) Can chlorophyll fluorescence be used to estimate photosynthetic production in the seagrass Zostera noltii? J Exp Mar Biol Ecol 307:207-216

> Silva J, Santos R (2009) Reply to comments of G. Abril on 'Underwater measurements of carbon dioxide evolution in marine plant communities: a new method' by J. Silva and R. Santos [Estuarine, Coastal and Shelf Science 78(2008) 827-830]. Estuar Coast Shelf Sci 82:361-362

Silva J, Santos R, Calleja ML, Duarte CM (2005) Submerged versus air-exposed intertidal macrophyte productivity: from physiological to community-level assessments. J Exp Mar Biol Ecol 317:87-95

Silva J, Feijóo P, Santos R (2008) Underwater measurements of carbon dioxide evolution in marine plant communities: a new method. Estuar Coast Shelf Sci 78:827-830

Smith RD, Dennison WC, Alberte RS (1984) Role of seagrass photosynthesis in root aerobic processes. Plant Physiol 74: 1055-1058

Strickland JDH, Parsons TR (1972) A practical handbook of seawater analysis. Fish Res Board Canada 167, Ottawa

Terrados J, Ros JD (1995) Temperature effects on photosynthesis and depth distribution of the seagrass Cymodocea nodosa (Ucria) Ascherson in a mediterranean coastal lagoon: the Mar Menor (SE Spain). PSZNI Mar Ecol 16:133-144

$>$ Turner SJ, Schwarz AM (2006) Biomass development and photosynthetic potential of intertidal Zostera capricorni in New Zealand estuaries. Aquat Bot 85:53-64

van Kooten O, Snel JFH (1990) The use of chlorophyll fluorescence nomenclature in plant stress physiology. Photosynth Res 25:147-150

Vermaat JE, Verhagen FCA (1996) Seasonal variation in the intertidal seagrass Zostera noltii Hornem.: coupling demographic and physiological patterns. Aquat Bot 52:259-281

Wahbeh MI (1983) Productivity and respiration of three seagrass species from the Gulf of Aqaba (Jordan) and some related factors. Aquat Bot 15:367-374

Walker D (1987) The use of the oxygen electrode and fluorescence probes in simple measurements of photosynthesis. Oxygraphics, Sheffield

- Williams SL, McRoy CP (1982) Seagrass productivity: the effect of light on carbon uptake. Aquat Bot 12:321-344

Zavodnik N, Travizi A, De Rosa S (1998) Seasonal variations in the rate of photosynthetic activity and chemical composition of the seagrass Cymodocea nodosa (Ucr.) Asch. Sci Mar 62:301-309

Zimmerman RC, Kohrs DG, Steller DL, Alberte RS (1997) Impacts of $\mathrm{CO}_{2}$ enrichment on productivity and light requirements of eelgrass. Plant Physiol 115:599-607 